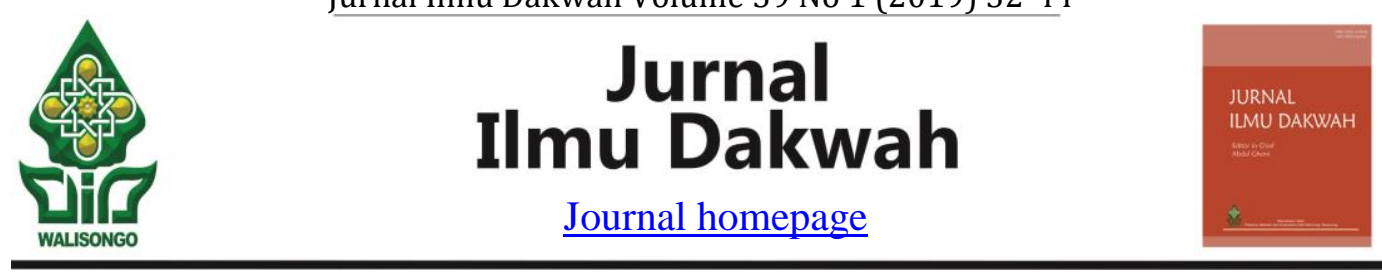

\title{
Prinsip-Prinsip Pemberdayaan Masyarakat dalam Perspektif Al Qur'an
}

\author{
Ulfi Putra Sany1) \\ 1IAIN Salatiga \\ email: ulfaputra@iainsalatiga.ac.id
}

\begin{abstract}
Becoming a challenge for every country and society, poverty is a problem that must be overcome. In Islam, it is also viewed as a disease that must be cured. One of the effective instruments of poverty alleviation is community empowerment. Community empowerment is methods used by individuals, groups and communities so they are able to manage the environment, achieve their own goals, work and help each other to maximize their quality of life. In the Qur'an there are many verses that speak about theme of community empowerment. This paper discusses community empowerment according to the Qur'anic perspective using thematic interpretation methods. The principles of community empowerment in the Qur'an are the principle of ukhuwwah, ta'awun principle, and the principle of equality. The steps of empowerment as mentioned in the Qur'an include continuous self-development, encouraging zakat and infaq programs, conducting training and skills education for the community, and avoiding economic behaviors prohibited by Islam such as hoarding and monopoly (ihtikar).
\end{abstract}

Keywords: Community empowerment, thematic interpretation, poverty alleviation

\begin{abstract}
Abstrak
Kemiskinan merupakan masalah yang harus diatasi dan menjadi tantangan bagi setiap negara dan masyarakat. Islam juga memandang kemiskinan sebagai penyakit yang harus disembuhkan. Karena kemiskinan dekat dengan kekufuran. Salah satu instrumen pengentasan kemiskinan yang efektif adalah dengan melakukan pemberdayaan masyarakat. Yang dimaksud dengan pemberdayaan masyarakat adalah cara dan metode yang digunakan individu, kelompok dan komunitas sehingga mereka menjadi mampu mengelola lingkungan dan mencapai tujuan mereka sendiri, dan dengan demikian mampu bekerja dan membantu satu sama lain untuk memaksimalkan kualitas hidup mereka. Dalam Al Quran terdapat banyak ayat yang membicarakan tema pemberdayaan masyarakat. Tulisan ini membahas pemberdayaan masyarakat menurut perspektif Al Qur'an dengan menggunakan metode penafsiran tematik. Prinsip-prinsip pemberdayaan masyarakat dalam $\mathrm{Al}$
\end{abstract}


Quran yaitu prinsip ukhuwwah, prinsip ta'awun, dan prinsip persamaan derajat. Langkah-langkah pemberdayaan sebagaimana disebutkan Al Qur'an antara lain pengembangan diri yang kontinyu, mendorong program zakat dan infaq, melakukan pembinaan dan pendidikan ketrampilan bagi masyarakat, dan tidak melakukan perilaku ekonomi yang dilarang oleh agama seperti menimbun harta (hoarding) dan monopoli (ihtikar).

Kata kunci: Pemberdayaan masyarakat, tafsir tematik, pengentasan kemiskinan

\section{PENDAHULUAN}

Al Quran merupakan wahyu yang diturunkan Allah kepada Rasulullah SAW. Al Quran adalah kitab suci yang tidak hanya berfungsi sebagai sumber hukum tetapi juga sebagai sumber inspirasi bagi umat Islam. Al Quran mengandung solusi bagi permasalahan dan shalih li kulli zaman wa makan. Artinya bahwa Al Quran mengandung prinsip-prinsip dan undang-undang yang bisa menjadi sumber pemecahan berbagai masalah yang dihadapi umat manusia.

Salah satu masalah yang kita hadapi adalah masalah kemiskinan. Masalah ini merupakan masalah yang dihadapi negara dan masyarakat. Sejarah mencatat banyak konflik yang terjadi di dunia yang lahir dari kesenjangan antara si kaya dengan si miskin. Islam sendiri menaruh perhatian yang besar terhadap masalah kemiskinan. Islam memandang kemiskinan sebagai hal yang harus diatasi, bahkan Rasulullah pernah bersabda bahwa kemiskinan adalah sesuatu yang dapat mendekatkan diri kepada kekufuran.

Al Quran kemudian menawarkan sebuah solusi guna mengubah kesenjangan dalam rizki tersebut menjadi sumber kebaikan dan kerukunan. Al Quran banyak mengandung ayat-ayat yang mengajak manusia untuk bersama-sama berkontribusi memberdayakan masyarakatnya guna mengentaskan kemiskinan. Pemberdayaan masyarakat merupakan salah satu instrumen pengentasan kemiskinan yang efektif karena dalam program pemberdayaan masyarakat didorong untuk mengubah diri mereka sendiri dan dilatih untuk mandiri. Islam sangat mendorong dan menganjurkan pemeluknya untuk saling tolong-menolong dalam kebaikan. Program pemberdayaan masyarakat sejalan dengan semangat Islam dan umatnya untuk menjadi agama yang rahmatan lil 'alamin. Islam mempunyai visi agar pemeluknya menjadi agen penyebar rahmat Allah dimuka bumi ini. Allah SWT berfirman:

"Dan Kami tidak mengutus engkau (Muhammad) melainkan untuk menjadi rahmat bagi seluruh alam" (QS. Al Anbiya [21]:107).

Untuk menggali pesan-pesan ilahi di dalam Al Quran para ulama menempuh beberapa metode penafsiran. Salah satu metode tafsir yang banyak digunakan para ulama dewasa ini adalah metode tafsir tematik atau maudhu'i. Metode tafsir ini digunakan ketika seorang mufassir ingin membahas sebuah tema atau permasalahan dan mengungkap bagaimana perspektif Al Qur'an mengenai permasalahan tersebut. Tata cara penafsiran dengan metode ini adalah melalui pengumpulan ayat Al Quran yang berkaitan dengan tema bahasan, kemudian ayat-ayat tersebut dikaji secara lengkap dan menyeluruh dari berbagai sisi permasalahannya (Muslim, 2000:16). Untuk mengetahui bagaimana pandangan Al Quran tentang pemberdayaan masyarakat, maka digunakanlah metode tafsir tematik dalam kajian ini.

Tema pemberdayaan masyarakat layak diangkat sebagai bahasan karena pemberdayaan masyarakat merupakan salah satu metode pengentasan kemiskinan yang efektif. Kemiskinan merupakan salah satu momok semua negara dan menjadi 
salah satu sumber konflik dan berbagai masalah sosial kemasyarakatan. Para ekonom dan pemerhati pembangunan dewasa ini tidak hanya memperhatikan angka pertumbuhan ekonomi, tetapi juga memperjuangkan bagaimana pertumbuhan ekonomi itu bisa dinikmati oleh semua lapisan masyarakat. Dengan kata lain, pemerintah juga berupaya mewujudkan pemerataan pembangunan dan mengurangi angka ketimpangan pendapatan (income inequality).

Paradigma pembangunan nasional sudah banyak berubah dari yang tadinya bersifat sentral dan terpimpin, menjadi pembangunan yang tersebar (decentralized) dan melibatkan partisipasi berbagai elemen masyarakat. Hal ini ditandai dengan disahkannya undang-undang otonomi daerah. Sebagai konsekuensinya, peran serta masyarakat dalam pembangunan nasional menjadi penting, karena masyarakat merupakan pelaku pembangunan yang sebenarnya. Pemberdayaan masyarakat adalah salah satu upaya mengikutsertakan masyarakat yang relatif tertinggal dalam kegiatan dan program pembangunan, sehingga mereka dapat meningkatkan taraf hidup mereka.

\section{Pengertian Pemberdayaan}

Pemberdayaan (empowerment) berasal dari kata dasar daya (power) yang berarti kemampuan atau kekuatan. Menurut Kamus Besar Bahasa Indonesia, pemberdayaan merupakan proses, cara, perbuatan memberdayakan. Secara umum, pemberdayaan merupakan suatu proses memberikan daya (power) bagi suatu komunitas atau kelompok masyarakat untuk bertindak mengatasi masalahnya, serta mengangkat taraf hidup dan kesejahteraan mereka.

Pemberdayaan sebenarnya memiliki arti yang berbeda-beda bergantung pada konteks dan kondisi sosial yang ada. Metode pemberdayaan di satu tempat pada satu masyarakat, berbeda dengan tempat lain, pada masyarakat yang lain, bergantung pada kondisi tempat tersebut. membuat sebuah definisi pasti pada kata pemberdayaan merupakan hal yang sulit dilakukan karena konsep pemberdayaan berbeda-beda bergantung pada situasi yang ada.

Pemberdayaan menurut Adams (2003:8) berarti cara dan metode yang digunakan individu, kelompok dan atau komunitas sehingga mereka menjadi mampu mengelola lingkungan dan mencapai tujuan mereka sendiri, dan dengan demikian mampu bekerja dan membantu satu sama lain untuk memaksimalkan kualitas hidup mereka. Kata pemberdayaan pada medio 80-an banyak dipakai pada diskursus ketimpangan jender dan diskriminasi antar ras dan warna kulit. Pada diskursus ini pemberdayaan dimaknai sebagai upaya memberikan pembinaan kepada perempuan dan ras yang termarjinalkan. Walaupun begitu, konsep pemberdayaan sebenarnya tidak hanya berkaitan dengan masalah ketimpangan gender, ras, dan suku bangsa, akan tetapi juga berkaitan dengan masalah ekonomi dan kemiskinan (Calvès, 2009). Dewasa ini, kata pemberdayaan erat hubungannya dengan masalah pengentasan kemiskinan.

\section{Pandangan al Quran tentang pemberdayaan masyarakat}

Islam memandang masyarakat sebagai sebuah sistem yang individunya saling membutuhkan dan saling mendukung. Antar individu masyarakat mempunyai hubungan yang idealnya saling menguntungkan. Kesenjangan dalam hal pendapatan ekonomi merupakan sebuah potensi yang dapat dimanfaatkan guna memupuk kerukunan dan silaturahim antar sesama. Islam mendorong pelaksanaan pemberdayaan masyarakat dengan berpegang pada 3 prinsip utama; ketiga prinsip itu adalah Prinsip ukhuwwah, Prinsip ta'awun, dan Prinsip persamaan derajat, Prinsip-prinsip tersebut akan dijelaskan di bawah ini. 
Pertama, prinsip ukhuwwah. Ukhuwwah dalam bahasa arab berarti persaudaraan. Prinsip ini menegaskan bahwa tiap-tiap muslim saling bersaudara, walaupun tidak ada pertalian darah antara mereka. Rasa persaudaraan menjamin adanya rasa empati dan merekatkan silaturahim dalam masyarakat. Prinsip ini berdasarkan pada firman Allah SWT

\begin{abstract}
"Innamal-mu'minụna ikhwatun fa așlihụ baina akhawaikum wattaqullāha la'allakum tur-ḥamụn."

"Sesungguhnya orang-orang mukmin itu bersaudara, karena itu damaikanlah antara kedua saudaramu (yang berselisih) dan bertakwalah kamu kepada Allah agar kamu mendapat rahmat." (QS. Al-Hujurat [49]:10)
\end{abstract}

Rasulullah mengumpamakan umat Islam sebagai sebuah bangunan yang saling menguatkan satu sama lain. ${ }^{1}$ Di hadis lain Beliau berpesan bahwa umat Islam hendaknya bersikap saling mencintai, mengasihi dan menyayangi terhadap sesama layaknya sebuah tubuh, di mana jika ada satu bagian yang merasa sakit, maka anggota tubuh yang lain akan susah tidur dan merasakan demam. ${ }^{2}$

Dalam konteks pemberdayaan, ukhuwwah merupakan motif yang mendasari seluruh upaya pemberdayaan masyarakat. Rasulullah memiliki visi masyarakat muslim yang saling menolong dan saling menanggung kesulitan secara bersama. Islam mendorong pemeluknya untuk meringankan beban saudaranya yang dilanda kesulitan melalui sabda Rasulullah SAW. "Barang siapa yang melapangkan kesusahan dunia dari seorang mukmin, maka Allah melapangkan darinya satu kesusahan di hari kiamat." 3 Islam merupakan agama yang menanamkan kepedulian dalam diri pemeluknya.

Kedua, prinsip ta'awun. Allah SWT mendorong manusia untuk saling tolongmenolong sesamanya. Allah SWT berfirman

“... wa ta'āwanụ 'alal-birri wat-taqwā wa lā ta'āwanụ 'alal-ismi wal'udwāni wattaqullāh, innallāha syadīdul-'iqāb."

Artinya: "Dan tolong-menolonglah kamu dalam (mengerjakan) kebajikan dan takwa dan jangan tolong-menolong dalam berbuat dosa dan permusuhan. Bertakwalah kepada Allah, sungguh, Allah sangat berat siksaan-Nya." (QS. Al-Maidah [5]:2)

Prinsip ta'awun atau tolong-menolong ini merupakan prinsip yang utama dalam pelaksanaan pemberdayaan masyarakat. Karena sesungguhnya program pemberdayaan itu adalah sebuah upaya menolong individu dan masyarakat yang membutuhkan bantuan dan bimbingan. Upaya pemberdayaan harus dimulai dari rasa kepedulian dan niat menolong individu dan masyarakat yang membutuhkan. Hal ini berasal dari rasa persaudaraan yang tumbuh dari ikatan ukhuwwah.

Prinsip ta'awun atau tolong-menolong ini juga dapat diartikan sebagai sebuah sinergi antara berbagai pihak yang berkepentingan demi terwujudnya pemberdayaan yang optimal. Pemberdayaan masyarakat adalah proses kolaboratif, maka hendaknya

\footnotetext{
${ }^{1}$ Hadis diriwayatkan oleh Imam Bukhari No. 5594

${ }^{2}$ Hadis diriwayatkan oleh Imam Muslim No. 4691

${ }^{3}$ Hadis diriwayatkan oleh Imam Muslim No. 4873
} 
seluruh pihak saling membantu demi terwujudnya tujuan bersama. Pemberdayaan bukanlah tanggung jawab pihak tertentu saja, melainkan tanggung jawab seluruh pihak terkait. Pemerintah tidak akan mampu menyelesaikan masalah sendiri tanpa bersinergi dengan pihak lain. Dengan ta'awun, pemerintah, lembaga zakat, para ulama, organisasi Islam dan berbagai LSM dapat bahu-membahu memadukan kekuatan finansial, manajemen, sumber daya manusia, metodologi, dan penentuan kebijakan sehingga tercipta sinergi yang efektif dalam melaksanakan pemberdayaan dan mengentaskan kemiskinan.

Ketiga, prinsip persamaan derajat antar umat manusia. Islam telah memproklamirkan persamaan derajat antar umat manusia sejak 14 abad yang lalu. Allah SWT berfirman:

"Yā ayyuhan-nāsu innā khalaqnākum min żakariw wa unśā wa ja'alnākum syu'ụbaw wa qabāila lita'ārafụ, inna akramakum 'indallāhi atqākum, innallāha 'alīmun khabīr."

Artinya: "Wahai manusia! Sungguh, Kami telah menciptakan kamu dari seorang laki-laki dan perempuan, kemudian Kami jadikan kamu berbangsa-bangsa dan bersuku-suku agar kamu saling mengenal. Sesungguhnya yang paling mulia di antara kamu disisi Allah adalah orang yang paling bertakwa. Sungguh, Allah Maha Mengetahui. Mahateliti." (QS. Al-Hujurat [49]:13)

Ayat diatas menegaskan persamaan derajat antar umat manusia, dan bahwa kemuliaan yang ada di sisi Allah hanyalah berdasarkan iman dan takwa. Ayat di atas juga menekankan bahwa pada dasarnya perbedaan harta dan kekayaan tidak menjadi sumber perpecahan, akan tetapi menjadi wasilah untuk tolong-menolong dan saling membantu. Allah SWT berfirman dalam ayat lain

"A hum yaqsimụna raḥmata rabbik, naḥnu qasamnā bainahum ma'īsyatahum fil-hayātid-dun-yā wa rafa'nā ba'ḍahum fauqa ba'ḍin darajātil liyattakhiża ba'ḍhum ba'ḍan sukhriyyā, wa raḥmatu rabbika khairum mimmā yajma'ụn"

Artinya: Apakah mereka yang membagi-bagi rahmat Tuhanmu? Kami telah menentukan antara mereka penghidupan mereka dalam kehidupan dunia, dan Kami telah meninggikan sebagian mereka atas sebagian yang lain beberapa derajat agar sebagian mereka dapat memanfaatkan sebagian yang lain. Dan rahmat Tuhanmu lebih baik dari apa yang mereka kumpulkan (QS. Az-Zukhruf [43]:32).

Menurut banyak ahli tafsir (Athiyyah, 1984:25.201), kata sukhriyya dalam ayat ini mengandung arti memanfaatkan dan mempekerjakan. Ayat ini mengandung arti bahwa manusia dilebihkan sebagian atas sebagian yang lain dalam rangka pemenuhan kebutuhan umat manusia secara umum, dan bukan untuk berbanggabangga dan saling merendahkan. Ayat ini mengarahkan manusia untuk saling membantu, karena manusia adalah makhluk sosial yang membutuhkan orang lain. Tidak ada yang mampu memenuhi kebutuhannya tanpa bantuan dari orang lain. Dalam konteks pemberdayaan masyarakat, ayat ini merupakan dorongan bagi semua pihak untuk terus bersama memperbaiki dan meningkatkan taraf hidup dan kesejahteraan masyarakat. Karena dalam setiap komunitas pasti ada potensi yang bisa diberdayakan. “... dan rahmat-Ku meliputi segala sesuatu ..." (QS. Al-A'raaf [7]:156). 


\section{Langkah-Langkah Pemberdayaan Masyarakat Dalam Al Quran \\ 4.1. Pengembangan Diri yang Berkesinambungan}

Pemberdayaan harus menanamkan kemandirian pada diri masyarakat yang diberdayakan. Hal ini guna menghindari tumbuhnya ketergantungan pada pemerintah atau organisasi yang melaksanakan pemberdayaan. Masyarakat yang diberdayakan lebih mengetahui potensi dan kebutuhan mereka sehingga mereka bisa mengelola pelaksanaan pemberdayaan tersebut sesuai dengan kebutuhan. Masyarakat yang diberdayakan sepatutnya membentuk sendiri sebuah organisasi yang mengarahkan dan memandu jalannya pemberdayaan. Menyerahkan kontrol pelaksanaan pemberdayaan kepada pihak luar dapat menimbulkan ketergantungan dan justru mengganggu penanaman daya yang diinginkan (Moeljadi, et. al, 2018). Langkah ini telah ditegaskan Allah dalam Al Quran

"innallāha lā yugayyiru mā biqaumin hattā yugayyiru mā bi 'anfusihim, wa iżā arādallāhu biqaumin sū'an fa lā maradda lah, wa mà lahum min dụnihī miw wāl."

Artinya: "Sesungguhnya Allah tidak akan mengubah keadaan suatu kaum sebelum mereka mengubah keadaan mereka sendiri. Dan apabila Allah menghendaki keburukan pada suatu kaum maka niscaya tidak ada yang mampu menolaknya, dan sekali-kali tidak ada pelindung bagi mereka selain Dia. (QS. Ar-Ra'd[13]:11).

Ayat di atas menegaskan bahwa Allah tidak akan mengubah keadaan dan martabat suatu masyarakat, kecuali mereka mengubah keadaan mereka sendiri. Manusia diminta untuk berusaha meningkatkan kompetensi dan bekerja keras demi mengubah nasib mereka sendiri. Ayat ini juga mendorong kemandirian dalam jiwa masyarakat. Tujuan pemberdayaan adalah menjadikan masyarakat dan komunitas penerima program pemberdayaan mampu mengubah nasib mereka dan meningkatkan kesejahteraan dan taraf hidup mereka. Derajat keberdayaan yang pertama adalah kesadaran dan keinginan untuk berubah (Firmansyah, 2012). Tanpa keinginan untuk memperbaiki diri, masyarakat akan sulit untuk dapat meningkatkan taraf hidupnya.

Pembentukan karakter positif adalah kunci keberhasilan proses pemberdayaan. Masyarakat harus disadarkan bahwa Islam mendorong pemeluknya untuk berusaha mencari rizki Allah yang tersebar di muka bumi (QS. Al-Jumu'ah [62]:10). Allah tidak akan mengangkat martabat masyarakat tanpa usaha. Islam mengecam perilaku meminta-minta dan tidak mau berusaha. Rasulullah SAW bersabda dalam sebuah hadis yang diriwayatkan oleh Imam Bukhari, "Sesungguhnya, seorang di antara kalian membawa tali-talinya dan pergi ke bukit untuk mencari kayu bakar yang diletakkan di punggungnya untuk dijual untuk menutup kebutuhannya, adalah lebih baik daripada meminta-minta kepada orang lain, baik mereka memberi atau tidak". Allah telah menjamin rizki setiap makhluknya, jika mereka berusaha dan bertawakkal. Begitulah didikan dan arahan Rasulullah SAW untuk menjadikan umat Islam sebagai insaninsan yang terhormat dan terpandang, bukan umat yang lemah dan pemalas.

\subsection{Perintah Zakat Dan Infaq}

Zakat merupakan salah satu ibadah yang utama dalam ajaran Islam. Zakat berasal dari kata zaka yazkuu yang berarti berkah, tumbuh, suci dan bersih. Perintah untuk berzakat seringkali berdampingan dengan perintah untuk melaksanakan ibadah shalat, yaitu sebanyak 27 kali (Qaradawi, 1973:37). Hal ini menunjukkan pentingnya kedudukan zakat dalam Islam. Selain istilah zakat, Al Quran juga 
menggunakan istilah lain seperti infaq (QS. Al-Baqarah [2]:261) dan sedekah (QS. Al-Baqarah [2]:264). Zakat selain merupakan ibadah dalam rangka ber-taqarrub kepada Allah, juga mempunyai dimensi sosial berupa pemberdayaan masyarakat dan keluarga miskin. Zakat juga dapat difungsikan untuk memeratakan pendapatan, dan mengurangi kesenjangan antara si kaya dan si miskin.

\section{Allah SWT berfirman}

"Lan tanālul-birra hattā tunfiqụ mimmā tuhibbụn, wa mā tunfiqụ min syai 'in fa innallāha bihī 'alìm."

Artinya: "Kamu tidak akan memperoleh kebajikan, sebelum kamu menginfakkan sebagian harta yang kamu cintai. Dan apa pun yang kamu infakkan, tentang itu sungguh, Allah Maha Mengetahui." (QS. Ali Imran [3]:92)

Sejumlah kajian empiris menunjukkan bahwa zakat dapat berperan secara efektif mengurangi angka kemiskinan mustahiqnya. Studi Beik (2009) didasarkan pada survei terhadap 1195 keluarga responden di Provinsi DKI Jakarta. Hasil penelitian menunjukkan bahwa dana zakat yang didistribusikan mampu meningkatkan pendapatan mustahiq sebesar 9,82\%. Berdasarkan kajian ini, jumlah kemiskinan mustahik dapat dikurangi sebesar $16,80 \%$. Ini artinya, 16,80\% mustahik miskin dapat keluar dari garis kemiskinan setelah mendapat bantuan zakat selama periode penelitian. Selain itu, tingkat kedalaman kemiskinan mustahik juga dapat dikurangi. Zakat mampu mengurangi jarak pendapatan rata-rata mustahik terhadap garis kemiskinan dari Rp 475.858,78 menjadi Rp 409.726,40 atau sebesar 13,90\%. Demikian pula dengan rasio kesenjangan pendapatan dapat dikurangi sebesar $13,72 \%$.

Hasil yang sama juga ditunjukkan oleh Indeks Sen dan Indeks FGT (Foster-GreerThorbecke index) pasca penyaluran zakat. Tingkat keparahan kemiskinan mustahiq miskin dapat dikurangi masing-masing sebesar 26,69\% dan 36,70\% (Firmansyah, 2013). Angka ini menunjukkan, penyaluran zakat yang dikelola oleh lembaga amil zakat yang amanah dan profesional, berdampak kepada peningkatan kesejahteraan rumah tangga penerima zakat, dan bahkan dapat mengangkat keluarga mustahiq dari jurang kemiskinan.

Di antara berbagai sarana pemberdayaan masyarakat, zakat mempunyai salah satu potensi terbaik untuk dapat difungsikan dan dimanfaatkan masyarakat luas. Tetapi di sisi lain, pengelolaan zakat di Indonesia masih memerlukan pembenahan dan peningkatan. Hal ini karena zakat tidak dapat difungsikan sebagai sarana pemberdayaan masyarakat dan pengentasan kemiskinan secara maksimal jika "kue" zakat yang dibagi masih kecil. Oleh karena itu perlu upaya untuk memperbesar "kue" tersebut dengan memperluas basis muzakki dalam rangka meningkatkan penerimaan zakat.

Al Ghazali ketika berbicara mengenai cara menghimpun dan mengelola zakat, berpendapat bahwa pengelolaan zakat harus ditangani oleh institusi khusus ('amilin) yang independen dan jauh dari intervensi pemerintah dan pengadilan (Indra, 2017). Mubasirun (2013) mengemukakan beberapa model penggunaan zakat yang dapat diaplikasikan dalam program pemberdayaan masyarakat. Model penggunaan yang bersifat konsumtif antara lain;

\section{Bantuan biaya hidup}

Penyaluran zakat untuk bantuan biaya hidup dapat didistribusikan kepada fakirmiskin yang berdasarkan pengamatan amil zakat, memang membutuhkan bantuan 
biaya hidup. Amil zakat bisa melakukan koordinasi dengan tokoh masyarakat setempat dalam mencari dan menetapkan calon penerima bantuan biaya hidup dari amil zakat.

\section{Bantuan biaya Pendidikan}

Penyaluran dana zakat untuk bantuan biaya pendidikan dilakukan misalnya dengan memberikan beasiswa kepada siswa dari keluarga yang tidak mampu.

\section{Bantuan biaya kesehatan}

Program bantuan biaya kesehatan bisa berupa santunan untuk kesehatan, perawatan medis dan penyuluhan kesehatan bagi keluarga yang kurang mampu. Bantuan dapat juga berupa pengadaan ambulans gratis atau klinik kesehatan cumacuma. Penyaluran dana zakat pada program pemberdayaan masyarakat yang bersifat produktif dapat dilakukan dalam beberapa bentuk seperti:

Pertama, model dengan sistem in kind, yaitu dana zakat yang disalurkan diberikan dalam bentuk alat-alat produksi yang dibutuhkan oleh penerima zakat yang ingin berproduksi. Penyaluran alat produksi ini diberikan baik kepada mereka yang baru memulai usahanya maupun yang telah menjalankan usahanya dan berniat mengembangkan usaha yang telah ada.

Kedua, model qardhul hasan, yaitu peminjaman modal usaha dengan mengembalikan pokok hutang tanpa ada tambahan jasa. Modal yang dipinjam dikembalikan kepada amil zakat, akan tetapi hal ini tidak berarti bahwa modal itu tidak lagi menjadi hak mustahiq tersebut. Dalam artian, modal dapat dikembalikan lagi ke penerima zakat untuk dikembangkan lagi, atau disalurkan ke mustahiq lain. Dengan model ini diharapkan lembaga amil zakat bisa menjadi partner bagi penerima zakat dalam mengembangkan usahanya, bahkan dapat mengubah statusnya dari mustahiq menjadi muzakki. Pada model ini dana yang dikumpulkan lembaga amil zakat akan bergulir dari satu mustahiq ke mustahiq lainnya, jika mustahiq pertama sudah mengembalikan dana pinjaman baik sebagian atau sepenuhnya. Model ini juga disebut dengan sistem revolving fund.

Ketiga, mudharabah, yaitu sistem penanaman modal usaha dengan konsekuensi bagi hasil (profit-loss sharing). Model ini secara umum hampir sama dengan model qardhul hasan namun letak perbedaanya terletak pada pembagian hasil usaha antara mustahiq dan amil. Dalam konteks pemberdayaan masyarakat, zakat dapat menjadi senjata ampuh untuk membantu masyarakat dan keluarga yang tidak mampu. Allah sangat mencintai hambanya yang menggunakan rizki yang diterimanya untuk kebaikan.

\subsection{Pendidikan dan Pembinaan}

Ilmu dan ketrampilan merupakan salah satu faktor naiknya taraf hidup masyarakat. Oleh karena itu, pemberdayaan berbasis pembinaan dan pendidikan ketrampilan mutlak perlu dilakukan. Allah SWT berfirman

“... yarfa'illāhullażīna āmanụ mingkum wallażina ụtul-'ilma darajāt, wallāhu bimā ta'malụna khabīr."

Artinya: "... niscaya Allah akan mengangkat (derajat) orang-orang yang beriman di antara kamu dan orang-orang yang diberi ilmu beberapa derajat. Dan Allah Mahateliti apa yang kamu kerjakan. (QS. Al-Mujadilah[58]:11).

Ayat diatas mengajak seluruh elemen masyarakat untuk meningkatkan skill dan ketrampilan sebagai langkah konkret dalam meningkatkan taraf hidup. Hubungan 
pendidikan dan pemberdayaan dalam konteks ini difungsikan sebagai upaya untuk menggali potensi kelompok masyarakat untuk belajar dan berlatih untuk meningkatkan kompetensi dan kinerja mereka dalam pekerjaannya sekarang dan menyiapkan diri untuk peranan dan tanggung jawab mereka yang akan datang, dengan memaknai belajar mengetahui (learning to know), belajar berbuat (learning to do), belajar hidup bersama (learning to live together), dan belajar menjadi seseorang (learning to be).

Sulistiyani sebagaimana dikutip oleh Florensi dan Putro (2014) mengemukakan bahwa tahap-tahap pemberdayaan yang harus dilalui adalah:

1. Tahap penyadaran dan pembentukan perilaku menuju perilaku sadar dan peduli sehingga merasa membutuhkan peningkatan kapasitas diri

2. Tahap transformasi pengetahuan agar terbuka wawasan berpikir dan memberikan kecakapan dan ketrampilan dasar agar bisa mengambil peran dalam kegiatan pembangunan.

3. Tahap peningkatan kemampuan intelektual, kecakapan, dan ketrampilan sehingga terciptalah inisiatif dan kemampuan untuk berinovasi yang mengantarkan pada kemandirian.

Setelah terbentuk karakter yang positif, hal berikutnya adalah pemberian ketrampilan dan skill, serta penanaman inisiatif dan kemampuan untuk berinovasi.

\subsection{Larangan Iktinaz dan Ihtikar}

Islam telah merumuskan model penggunaan sumber daya dan kekayaan yang dikehendaki oleh Allah SWT. Islam memandang harta sebagai sebuah titipan, sebuah amanah yang suatu saat akan dimintai pertanggung jawabannya. Oleh karena itu penggunaan harta dan kekayaan sangat diperhatikan dan diatur oleh Al Quran dan Hadis.

Muhammad Baqer As-Sadr sebagaimana dikutip Mallat (2003:114-115) menyebutkan 3 prinsip dasar bagi aktivitas ekonomi dalam Islam. Yang pertama adalah kepemilikan ganda (multifold property). Hukum Islam membagi kepemilikan ke dalam 3 kategori: kepemilikan pribadi (private property), kepemilikan publik (public property) dan kepemilikan negara (statal property). Berbeda dengan sistem kapitalis yang mengagungkan kepemilikan pribadi dan memandang kepemilikan publik dan negara sebagai pengecualian, dan sistem sosialis yang mengutamakan kepemilikan publik dan negara dan memandang kepemilikan pribadi sebagai pengecualian, Islam mengakui 3 jenis kepemilikan dan menjaga hak masing-masing.

Yang kedua, kebebasan ekonomi terbatas. Ada 2 hal yang membatasi kebebasan dalam menggunakan kepemilikan pribadi, Batasan pertama bersumber dari dalam diri masing masing individu (subjective limits) batasan ini berupa nilai-nilai kedermawanan yang ditanamkan oleh Islam. Nilai-nilai ini menggerakkan individu untuk menggunakan harta pribadinya untuk kepentingan umum. Batasan kedua merupakan batasan yang bersumber dari luar diri individu (objective limits). Batasan ini berupa pelarangan dan pengharaman beberapa bentuk transaksi dan perilaku yang berefek negatif pada masyarakat seperti riba dan monopoli (ihtikar).

Yang ketiga, adalah keadilan sosial. Islam mengajarkan solidaritas dan mendorong umat Islam untuk mempraktekkannya dalam kehidupan. Dalam syariat Islam, keadilan sosial digalakkan melalui kewajiban zakat, anjuran untuk berinfak dan bersedekah, dan memberi makan orang yang membutuhkan. 
Islam mengakui hak kepemilikan pribadi individu dan bahkan memandangnya sebagai sesuatu yang harus dijaga. Islam mengakui hifzu al-mal atau memelihara dan menjaga harta benda sebagai salah satu maslahat yang dijaga dalam Islam. Walaupun demikian, ada rambu-rambu yang harus ditaati dalam penggunaan harta yang telah diberikan oleh Allah kepada manusia.

Allah SWT berfirman

"Mā afā `allāhu 'alā rasụlihī min ahlil-qurā fa lillāhi wa lir-rasụli wa liżil-qurbā wal-yatāmā wal-masākīni wabnis-sabīli kai lā yakụna dụlatam bainal-agniyā'i minkum, wa mā àtākumur-rasụlu fa khużụhu wa mā nahākum 'an-hu fantahụ, wattaqullāh, innallāha syadīdul-'iqāb."

Artinya: "Harta rampasan (fay') dari mereka yang diberikan Allah kepada Rasul-Nya (yang berasal) dari penduduk beberapa negeri adalah untuk Allah, Rasulullah, kerabat rasul, anak-anak yatim, orang-orang miskin dan untuk orang-orang yang dalam perjalanan, agar harta itu jangan hanya beredar di antara orang-orang yang kaya saja di antara kamu. Apa yang diberikan Rasul kepadamu maka terimalah. Dan apa yang dilarangnya bagimu maka tinggalkanlah. Dan bertakwalah kepada Allah. Sungguh, Allah sangat keras hukumannya." (QS. Al-Hasyr [59]:7)

Kata "agar harta itu jangan hanya beredar di antara orang-orang yang kaya saja di antara kamu." Merupakan pedoman umum ekonomi Islam. Islam mengakui dan menjaga kepemilikan harta secara pribadi namun membatasinya agar harta dan sumber daya yang ada, tidak hanya beredar dan dikuasai oleh orang-orang yang kaya saja, sedangkan orang-orang yang miskin tidak dapat mengakses sumber daya tersebut. Islam berusaha mewujudkan pemerataan akses sumber daya tersebut dengan menetapkan hukum dan aturan yang menjamin tersebarnya rizki Allah secara lebih merata. Beberapa aturan tersebut antara lain perintah untuk berzakat, berinfaq, memberi makan anak yatim dan fakir miskin, melarang riba, dan mendorong transaksi keuangan berbasis profit-loss sharing (PLS). Seluruh hukum dan aturan yang disyariatkan dalam Islam ditetapkan demi mewujudkan keadilan sosial dalam masyarakat.

Pemberdayaan masyarakat merupakan salah satu upaya mewujudkan cita-cita Islam berupa masyarakat yang saling peduli. Allah SWT juga melarang penimbunan sumber daya baik itu dalam bentuk uang maupun komoditi lainnya. Allah SWT Berfirman

“... wallażina yaknizụnaż-żahaba wal-fị̣ḍata wa lā yunfiqụnahā fi sabīlillāhi fa basysyir-hum bi'ażābin alīm.

Yauma yuḥmā 'alaihā fì nāri jahannama fa tukwā bihā jibāhuhum wa junụbuhum wa zuhụruhum, hāżā mā kanaztum li anfusikum fa żuqu mā kuntum taknizụn."

Artinya: "... Dan orang-orang yang menyimpan emas dan perak dan tidak menginfakkannya di jalan Allah, maka berikanlah kabar gembira kepada mereka (bahwa mereka akan mendapat) azab yang pedih. (Ingatlah) pada hari ketika emas dan perak dipanaskan dalam neraka Jahannam, lalu dengan itu disetrika dahi, lambung, dan punggung mereka (seraya dikatakan) kepada mereka, "inilah harta bendamu yang kamu simpan untuk dirimu sendiri, maka 
rasakanlah (akibat dari) apa yang kamu simpan itu." (QS. At Taubah [9]:34-35)

Penimbunan harta dalam Islam disebut sebagai iktinaz, berasal dari akar kata kanaza (كنز), yang dalam konteks ini berarti menyimpan dan mengumpulkan harta. Penimbunan yang dilarang pada ayat tersebut adalam penimbunan emas dan perak, yang merupakan mata uang pada zaman Rasulullah SAW. Al Ghazali, sebagaimana dikutip oleh Oran (2007) menyebutkan 3 model pemanfaatan uang yang dilarang; iktinaz, riba dan pemalsuan uang. Mengenai iktinaz, Al Ghazali menegaskan kedudukan uang yang penting sebagai medium transaksi dan sangat mengecam penimbunan uang dan harta karena merusak system perputaran uang dan peredaran sumber daya. Al Ghazali bahkan menilai iktinaz sebagai dosa yang besar, setara dengan kufur, karena iktinaz menghambat tersebarnya rahmat Allah ke seluruh makhluknya dengan merusak peran uang sebagai medium transaksi yang penting bagi lancarnya kegiatan ekonomi.

Pelarangan iktinaz tidak dipahami sebagai pelarangan terhadap kepemilikan pribadi, karena hal itu diakui bahkan dijaga sepenuhnya dalam Islam. Pelarangan iktinaz dan riba dikarenakan efek negatif terhadap perekonomian yang akan timbul. Pelarangan iktinaz tidak hanya dimaksudkan untuk memahamkan umat Islam akan bahaya iktinaz. Akan tetapi merupakan sebuah perintah untuk menjauhi iktinaz.

Iktinaz erat hubungannya dengan riba sebagai dua perilaku ekonomi yang dilarang dalam Islam. Islam menjaga keseimbangan supply dan demand uang. Islam melarang riba untuk menjaga supply uang, dan melarang iktinaz untuk menjaga demand uang. Dua pengharaman ini berjalan beriringan menjaga kestabilan ekonomi masyarakat. Pelarangan riba saja tidaklah cukup untuk menjaga ekonomi umat Islam. Allah SWT tidak hanya menghalangi perilaku iktinaz dengan ancaman hukuman di akhirat, melainkan secara aktif mensyariatkan hukum dan aturan untuk mengatasi masalah penimbunan sumber daya yang mungkin terjadi.

Selain mengharamkan penimbunan harta, Islam juga melarang perilaku monopoli. Monopoli dalam perspektif Islam memiliki pengertian yang berbeda dengan monopoli dalam perspektif ekonomi konvensional. Dalam perspektif ekonomi Islam, secara etimologi (ihtikar) berasal dari kata al-hukr yang artinya menahan. Ibnu Faris menyebutkan, al-hukr berarti habs ath-tha'am muntazhiran ghala'ihi, yaitu menahan bahan makanan dan menunggu naiknya harga (Faris, 1979).

Secara terminologis, ihtikar berarti menahan atau menimbun (hoarding) barang dengan sengaja terutama pada saat kelangkaan harga barang dengan tujuan untuk menaikkan harga barang di kemudian hari dan mendapatkan keuntungan (Johan, 2015). Praktek ihtikar akan menciptakan kelangkaan barang semu (artificial scarcity) sehingga menaikkan harga barang, menurunkan efisiensi dan merugikan masyarakat luas. Islam melalui sabda Rasulullah SAW melarang praktek ihtikar. "Umar bin Khattab berkata, "Saya mendengar Rasulullah SAW bersabda: Barangsiapa yang melakukan monopoli makanan atas kaum muslim Allah akan menimpakan kepadanya penyakit dan kebangkrutan." Dalam hadis lain Rasulullah SAW bersabda, "Barangsiapa yang melakukan monopoli dengan tujuan agar harga naik atas kaum muslim, maka dia telah melakukan dosa."

Ada kemiripan antara praktik ihtikar dan iktinaz, yang membedakan adalah motif yang melatarbelakangi perilaku tersebut. Iktinaz berasal dari keengganan untuk menginfakkan harta benda, sedangkan ihtikar berasal dari keinginan untuk meraup untung yang sebanyak-banyaknya lewat penjualan komoditi yang harganya telah naik. Terlepas dari itu dampak keduanya sama, yaitu menimbulkan kerugian dan memperburuk kondisi ekonomi masyarakat. 
Dalam kaitannya dengan pemberdayaan masyarakat, pengharaman iktinaz dan ihtikar dimaksudkan agar sumber daya yang ada dapat dimanfaatkan oleh masyarakat luas dan tidak hanya dinikmati oleh segelintir orang saja. Selain itu, praktik ihtikar dapat menaikkan harga-harga komoditi sehingga mengurangi daya beli masyarakat, dan pada akhirnya membuat masyarakat miskin mengalami kerugian.

\section{Kesimpulan}

Dalam Al Quran terdapat banyak ayat yang berkaitan dengan prinsip-prinsip pemberdayaan masyarakat. Al Quran juga menawarkan solusi nyata (practical solution) yang bisa diaplikasikan dalam membantu keberhasilan program pemberdayaan masyarakat. Ada tiga prinsip pemberdayaan masyarakat menurut perspektif Al Quran. Yang pertama adalah prinsip ukhuwwah. Islam mendorong umatnya untuk saling membantu satu sama lain, dalam kerangka ukhuwwah Islamiyah dan ukhuwah insaniyyah. Yang kedua adalah prinsip ta'awun. Prinsip ini menegaskan bahwa program pemberdayaan adalah tanggung jawab bersama, dan harus berlandaskan sinergi yang efektif antara pemangku kebijakan, praktisi dan penggiat sosial, dan masyarakat luas. Yang ketiga adalah prinsip persamaan derajat, di mana Islam menekankan kesamaan derajat antara umat manusia.

Menurut perspektif Al Quran ada beberapa langkah yang dapat dilakukan dalam membantu keberhasilan program pemberdayaan masyarakat. Yang pertama yaitu pengembangan diri yang berkesinambungan. Masyarakat yang menjadi klien program pemberdayaan dituntut agar mampu mengembangkan diri dan bekerja untuk meningkatkan taraf hidup dan nasib mereka. Yang kedua yaitu melakukan pendidikan dan pembinaan kepada masyarakat, di mana skill dan ketrampilan merupakan salah satu faktor yang menjadi penggerak ekonomi masyarakat. Yang ketiga adalah melaksanakan dan mendorong zakat dan infak, dua program yang sangat ampuh dalam mengangkat masyarakat dari garis kemiskinan. Yang juga dituntut adalah pengelolaan zakat yang lebih efisien dan professional, demi mewujudkan pemberdayaan yang lebih efektif. Yang terakhir adalah menjauhi perilaku ekonomi yang dilarang oleh agama Islam seperti penimbunan bahan pokok (hoarding) dan monopoli (ihtikar), karena perilaku tersebut merugikan masyarakat dan tidak sejalan dengan ajaran Islam yang mengusung semangat keadilan sosial.

Pemberdayaan masyarakat adalah salah satu instrumen penting dalam mengentaskan kemiskinan. Sebagai agama rahmatan lil 'alamin, Islam mendorong umatnya untuk mewujudkan keadilan sosial dan kesejahteraan bagi semua. Dalam perspektif Islam, program pemberdayaan masyarakat sangat sejalan dengan semangat dan ruh Islam yang mengkader pemeluk-pemeluknya untuk menjadi agen penyebar rahmat Allah SWT.

\section{Daftar Pustaka}

Adams, Robert. 2003. Social Work and Empowerment. New York: Palgrave MacMillan.

Faris, Ibnu Al-Qazwini. 1979. Mu'jam Maqayis Al Lughah. Beirut: Dar Al Fikr.

Athiyyah, Ibnu. 1984. At Tahrir wa At Tanwir. Tunis: Dar At Tunisiyah.

Beik, Irfan .Syauqi. 2009. Analisis Peran Zakat dalam Mengurangi Kemiskinan: Studi Kasus Domper Dhuafa Republika. Zakat \& Empowering. Jurnal Pemikiran dan Gagasan, 2(1), 1-11. http://www.imz.or.id/new/uploads/2011/10/AnalisisPeran-Zakat-dalam-Mengurangi-Kemiskinan.pdf 
Calvès, A. (2009). "Empowerment » : généalogie d'un concept clé du discours contemporain sur le développement. Revue Tiers Monde, 200(4), 735-749. https://doi.org/10.3917/rtm.200.0735.

Firmansyah, Hairi. 2012. Tingkat Keberdayaan Masyarakat dalam Program Pemberdayaan Masyarakat di Kota Banjar masin dan Kabupaten Tanah Lot. Jurnal Agribisnis Pedesaan, 2 https://media.neliti.com/media/publications/9264-ID-tingkatkeberdayaan-masyarakat-dalam-program-pemberdayaan-masyarakat-dikota-ban.pdf

Firmansyah. 2013. Zakat Sebagai Instrumen Pengentasan Kemiskinan dan Kesenjangan Pendapatan. Jurnal Ekonomi dan Pembangunan, 21(2), 179-190, http://dx.doi.org/10.14203/JEP.21.2.2013.61-72.

Florensi, Helen. \& Roestoto Hartojo Putro. 2014. Pelaksanaan Alokasi Dana Desa (ADD) dalam Memberdayakan Masyarakat Desa di Desa Cerme, Kecamatan Grogol, Kabupaten Kediri. Jurnal Kebijakan dan Manajemen Publik. Vol. 2 No. 1.

Indra, Fadhila Sukur. 2017. Management of Zakat Infaq and Sadaqah in Indonesia. Tasharruf: Journal Economic and Business of Islam. Vol. 2 No. 1. http://journal.iain-manado.ac.id/index.php/TJEBI/article/view/531

Johan, A. (2015). Monopoly Prohibition According to Islamic Law: A Law And Economics Approach. Mimbar Hukum - Fakultas Hukum Universitas Gadjah Mada, 27(1), 166-178. doi:http://dx.doi.org/10.22146/jmh.15904.

Mallat, Chibli. 1993. The Renewal of Islamic Law, Muhammad Baqer as-Sadr, Najaf and the Shi'I International. Cambridge: Cambridge University Press.

Moeljadi \& Pramono, S \& Yuniarsa, S.O. 2018. Exploring of coastal communities and economic empowermen to the environment impact in maritime. International Journal of Management and Business Research. 8 (2). 223-231. http://www.ijmbr.info/abstract.php?archiveid=152

Mubasirun, M. (2013). Distribusi Zakat dan Pemberdayaan Ekonomi Umat. INFERENSI: Jurnal Penelitian Sosial Keagamaan, 7(2), 493-512. doi:http://dx.doi.org/10.18326/infsl3.v7i2.493-512.

Muslim, Musthafa. 2000. Mabahits fi At Tafsir Al Maudhu'i. Damascus: Dar Al Qalam.

Oran, Ahmad. 2007. Iktinaz and Islamic Monetary Policy. Review of Islamic Economics. 2. 71-85.

Qaradawi, Yusuf. 1973. Fiqh Zakat. Beirut: Muassasah Ar Risalah.

Rappaport, Julian., \& Seidman, E. 1999. Handbook of Community Psychology. New York: Springer Science. 